\title{
INTEGRASI THE FOUR CS DALAM PEMBELAJARAN BAHASA DI ERA REVOLUSI INDUSTRI 4.0
}

\author{
Helaluddin ${ }^{1}$, Arinah Fransori ${ }^{2}$ \\ Universitas Islam Negeri Sultan Maulana Hasanuddin Banten
}

\begin{abstract}
The change of time requires the world of education to adapt with its paradigm, strategy, and learning patterns. Industrial revolution 4.0 determines the field of work which has been developed by technological advances. This kind of changes demand the world of education to shift its education system to produce those who need the skills needed at this time. There are several skills that is mandatory for students in this industrial revolution 4.0 era, namely critical thinking skills or problem solving, creativity, collaboration, and communication. The data in this article comes from various sources, such as national and international journal articles, seminar articles, and related books. Furthermore, the data is analyzed to be presented about the implementation of the 4Cs in language learning. This learning design is devoted for writing and speaking subjects by utilizing technology and social media which is identify the students.
\end{abstract}

Keywords: the four Cs, language learning, industrial revolution 4.0

\begin{abstract}
Abstrak: Perubahan zaman menuntut dunia pendidikan untuk mengubah paradigma, strategi, dan pola pembelajarannya. Hadirnya era revolusi industri 4.0 berpengaruh pada bidang pekerjaan yang mayoritas telah dikendalikan oleh kemajuan teknologi. Perubahan secara sporadis tersebut menuntut dunia pendidikan untuk menggeser sistem pendidikannya dalam menghasilkan lulusan yang memiliki keterampilan yang dibutuhkan pada era ini. Ada beberapa keterampilan yang harus dikuasai oleh mahasiswa di era revolusi industri $4.0 \mathrm{ini}$, yaitu critical thinking skill atau problem-solving, creativity, collaboration, dan communication. Data dalam artikel ini berasal dari berbagai sumber, seperti artikel jurnal nasional dan internasional, artikel seminar, dan buku-buku terkait. Selanjutnya, data tersebut dianalisis untuk menyajikan perspektif tentang implementasi The $4 C s$ dalam pembelajaran bahasa Indonesia. Desain pembelajaran tersebut dikhususkan pada pembelajaran menulis dan berbicara dengan memanfaatkan teknologi dan media sosial yang merupakan identitas bagi mahasiswa saat ini.
\end{abstract}

Kata-kata kunci: the four $C s$, pembelajaran bahasa, revolusi industri 4.0

\section{PENDAHULUAN}

Isu global yang makin ramai diperbincangkan dalam forum-forum ilmiah dan media massa saat ini adalah perihal era baru yang disebut dengan era revolusi industri 4.0. Era ini merupakan sebuah masa yang menempatkan manusia pada posisi "dimanjakan". Mengapa demikian? Dengan berkembangnya teknologi informasi saat ini, hampir semua aspek kehidupan manusia memberikan dampak pada aktivitas manusia yang semakin mudah dan fleksibel. Kondisi inilah yang seolah-olah memanjakan manusia dengan segala kebutuhan dan keperluannya.

Era revolusi industri generasi keempat hadir dengan memberikan berbagai tantangan khususnya bagi dunia pendidikan. Perubahan secara sporadis dan disruptif ini tentu harus disikapi dengan menyesuaikan diri terhadap perubahan tersebut. Pendidikan sebagai aspek penting bagi kehidupan manusia harus mampu

\footnotetext{
'Universitas Islam Negeri Sultan Maulana Hasanuddin Banten, Email: helaluddin国uinbanten.ac.id

${ }^{2}$ Universitas Indraprasta PGRI Jakarta, Email: arinah.fransari国unindra.ac.id
} 
menciptakan dan mempersiapkan generasi muda yang siap bersaing di era revolusi industri 4.0 saat ini. Keterampilanketerampilan yang beberapa puluh tahun lalu dibutuhkan mungkin tidak akan relevan lagi di era revolusi industri 4.0 saat ini.

Seperti yang telah kita ketahui, kehadiran era revolusi industri 4.0 bersamaan dengan keberadaan kita yang memasuki abad ke-21. Penanda abad ke-21 dan revolusi industri generasi keempat ini adalah lahirnya kecanggihan teknologi dan informasi yang kian tak terbendung. Perubahan ini membawa sederet pengaruh dan tantangan yang harus disikapi dengan bijak bagi pelaku dunia pendidikan. Tipisnya jarak antara realitas maya dan realitas nyata semakin mengukuhkan bahwa kita harus berupaya untuk segera menyesuaikan dengan perubahan ini.

Sekadar menoleh ke belakang, masih banyak lembaga pendidikan di Indonesia yang menerapkan sistem tradisional dalam aktivitasnya. Hal ini perlu menjadi perhatian serius bagi pemerintah dan kalangan akademisi untuk membenahi sistem pendidikan tersebut. Kita tentu tidak ingin mendengar lagi bahwa pendidikan kita masih mengadopsi sistem "jadul" sehingga menjadi sesuatu yang kontraproduktif dengan laju perubahan zaman dan perkembangan teknologi. Intinya, pendidik dan lembaga pendidikan harus beradaptasi dengan dunia baru tersebut agar pendidikan dapat berselancar di atas gelombang pergeseran dan bukan malah tenggelam di bawahnya (Sumardianta \& AW, 2018).

Selama bertahun-tahun, beberapa keterampilan yang diprioritaskan dalam program pendidikan di sekolah-sekolah umum adalah membaca, menulis, dan berhitung atau matematika. Di samping itu, saat ini sekolah-sekolah menawarkan kepada peserta didik seperti pembelajaran bahasa asing, seni, geografi, ilmu pengetahuan alam, dan studi sosial. Namun faktanya, semua itu belumlah dipandang cukup karena fokus utama saat ini adalah karir dan kesiapan perguruan tinggi (Freeman, 2016).

Sebuah survei yang dilakukan oleh empat lembaga terkemuka, yaitu The Conference Board, Coorporate Voices for Working Families, The Partnership for $21^{\text {st }}$ Century Skill, dan The Society for Human Resource Management pada tahun 2006 menemukan hasil yang cukup menarik. Hasil penelitian ini menyatakan bahwa lebih dari 400 pengusaha menyatakan bahwa di atas $50 \%$ karyawannya yang merupakan lulusan baru dinilai kurang dalam hal: (1) komunikasi lisan maupun tulisan, (2) profesionalisme atau etos kerja, dan (3) berpikir kritis atau problem-solving (Levin-Goldberg, 2012).

Di sisi lain, laporan tentang keterampilan abad ke-21 telah dikemukakan oleh sebuah lembaga/organisasi yang bernama The Educational Testing Service (ETS). Lembaga tersebut telah mempublikasikan artikelnya dengan judul Digital Transformation: A Literacy Framework for ICT Literacy pada tahun 2007. Dalam ulasannya, lembaga tersebut menguuraiakan beberapa keterampilan belajar pada abad ke-21, yaitu: (1) mengumpulkan informasi, mengorganisasikan dan mengolah informasi, (3) mengevaluasi kualitas, relevansi, dan kegunaan informasi, dan (4) mengeneralisasi keakuratan informasi melalui penggunaan sumber-sumber informasi yang ada.

$$
\text { Lebih lanjut, ETS juga }
$$
mengelompokkan beberapa keterampilan pada abad ke-21 menjadi beberapa kelompok. Kelompok pertama disebut dengan keterampilan pembelajaran dan inovasi, yang meliputi kemampuan berpikir kritis atau problem-solving, creativity atau innovation, collaboration, dan communication. Kelompok berikutnya disebut dengan istilah keterampilan literasi digital yang mencakup tentang literasi informasi, literasi media, dan literasi ICT (information communication technology). Terakhir, beberapa kompetensi dalam 
kelompok career \& life skill yang mencakup fleksibitas dan kemampuan beradaptasi, inisiatif, interaksi antar sosialbudaya, produktivitas, dan akuntabilitas.

Selanjutnya, berkaitan dengan era revolusi industri 4.0, World Economic Forum, (2015) menjabarkan beberapa kompetensi atau keterampilan yang harus dikuasai oleh para lulusan perguruan tinggi. Menurutnya, ada tiga komponen keterampilan abad ke-21, yaitu foundational literacies, competencies, dan keterampilan karakter. Dalam kelompok competencies, WEF membagi menjadi beberapa sub-kompetensi, yaitu: (1) berpikir kritis atau critical thinking/problem-solving, (2) kreativitas atau creativity, (3) kemampuan berkomunikasi, dan (4) kolaborasi. Keempat keterampilan tersebut dikenal dengan istilah the 4Cs atau super skills.

Mengingat pentingnya keempat kompetensi yang telah disinggung di atas, sudah seharusnya proses pembelajaran di perguruan tinggi memacu peserta didiknya untuk mencapai kompetensi tersebut. Setiap dosen diharapkan mengembangkan mata kuliahnya agar lulusannya mampu bersaing di dunia kerja era revolusi industri 4.0. Dalam mata kuliah bahasa Indonesia, dosen dapat menerapkan berbagai strategi pembelajaran pada empat ranah keterampilan berbahasa, yakni keterampilan mendengarkan, membaca, menulis, dan berbicara.

\section{REVOLUSI INDUSTRI 4.0}

Sesuai dengan namanya, era revolusi industri 4.0 merupakan fase lanjutan dari revolusi industri sebelumnya. Profesor Schwab, seorang ekonom Jerman memperkenalkan istilah ini pada tahun 2017 melalui bukunya berjudul The Fouth Industrial Revolution. menurutnya, era revolusi industri generasi keempat ini ditandai dengan perkembangan teknologi digital yang seolah-olah telah menyamarkan atau mengaburkan antara dimensi fisik, digital, dan biologis. Artinya, dalam kehidupan manusia saat ini seolah- olah tidak ada lagi sekat-sekat yang membatasi antar-dimensi tersebut.

Hadirnya revolusi industri 4.0 mengubah pola dan tatanan kehidupan masyarakat dunia secara fundamental. Era ini familiar juga disebut sebagai era disrupsi, sebuah era yang menghadirkan fenomena-fenomena yang tidak pernah kita bayangkan sebelumnya. Aspek-aspek kehidupan manusia semakin disamarkan dari sekat-sekat yang membatasinya. Hanya dengan gerakan jemari di gadget, seseorang dapat melakukan aktivitas seperti berbelanja, melakukan transaksi pembayaran, transfer, booking pesawat dan hotel, yang dulu harus dilakukan dengan mendatangi kantor atau pusat perbelanjaan

Merujuk pada sejarah perubahan industri dunia, telah terjadi perubahan secara mendasar semenjak abad ke-18. Perubahan pertama dalam dunia indutri itu disebut dengan istilah era revolusi industri 1.0. Revolusi ini merupakan perubahan pertama dalam bidang industri yang ditandai dengan beralihnya bidang pekerjaan dari pertanian dan perkebunan menjadi industri berbasis pabrik. Era ini identik dengan penemuan mesin uap yang benar-benar mengubah tatanan kehidupan masyarakat pada saat itu. Tenaga-tenaga manusia dan hewan sudah mulai digantikan dengan beberapa tenaga mesin. Artinya, terjadi efisiensi yang cukup besar sehingga menghasilkan keuntungan yang berlipat. Namun tidak dapat dimungkiri pula, terjadi pengurangan tenaga kerja karena sebagian pekerjaan tersebut telah diambil alih oleh peranan mesin.

Pada abad ke-19, mulai terjadi kembali perubahan besar yang disebut dengan era revolusi industri 2.0. Sebuah era yang benar-benar mulai mewujudkan halhal yang selama ini hanya menjadi impian manusia. The second revolution ini ditandai dengan berbagai penemuan teknologi yang didasari oleh energi listrik, penemuan pesawat telepon, hingga pesawat atau kapal terbang. Hal yang paling menonjol dalam era ini adalah mulainya pabrik-pabrik yang didasarkan pada produksi massal. Artinya, 
sistem produksi telah diatur untuk menghasilkan produk/barang dengan jumlah yang lebih banyak yang tidak dapat dikerjakan oleh tenaga manusia.

Pada abad ke-20, terjadi kembali perubahan besar dalam dunia industri dan disebut sebagai revolusi industri 3.0. Pada era ini, dunia industri diwarnai dengan penggunaan elektronik dan teknologi informasi dengan tujuan untuk efisiensi dan jumlah produksi. Artinya, bagaimana pabrik-pabrik dapat memproduksi barang dan jasa dalam jumlah yang besar namun dengan efisiensi waktu dan tenaga. Untuk itulah, digunakan pemrograman yang didasarkan pada teknologi dalam proses produksinya.

Terjadinya perubahan dalam dunia industri ini bukannya tanpa meninggalkan dampak. Ada berbagai konsekuensi yang harus terima oleh masyarakat dunia. Pergeseran pada era ini tidak hanya berlaku pada praktik produksi, distribusi, dan konsumsi makanan dan pelayanan tetapi juga merambah ke perubahan yang fundamental seperti pada cara hidup manusia secara individu dan strata sosial (Janíková \& Kowaliková, 2017). Pergeseran ini dimulai pada dekade kedua abad ke-21 ini yang ditandai dengan transformasi berbagai bidang, termasuk gaya hidup, pekerjaan, cara berpikir, dan lain-lain.

Saat ini, teknologi digital berdampak sistemik dan masif di seluruh aspek kehidupan manusia, baik bidang ekonomi, sosial, politik, dan bahkan pendidikan. Pada bidang ekonomi, kita dapat merasakan perubahannya semenjak makin menjamurnya e-commerce atau perdagangan elektronik yang hadir seperti bukalapak, traveloka, lazada, elevania, dan lain-lain. Munculnya berbagai startup ini memberikan kemudahan bagi masyarakat dalam berbelanja kebutuhannya tanpa harus datang ke department store atau toko. Di samping itu, industri transportasi juga mengalami perubahan yang drastis dan dapat dikatakan mengalami disrupsi. Kemapanan moda transportasi lama yang didominasi oleh ojek dan angkutan tradisional kini telah tergeser oleh kehadiran mode transportasi berbasis daring (dalam jaringan) atau online. Gojek, grab, dan uber merupakan beberapa moda transportasi yang kini mengusai di seluruh dunia walaupun pada awal kemunculannya banyak mendapat tentangan dari para pebisnis transportasi tradisional.

Revolusi industri 4.0 juga berpengaruh cukup signifikan dalam bidang pendidikan. Reorientasi pendidikan dari pola teacher centered learning menuju student centered learning mau tidak mau memang harus mengikutsertakan aplikasi teknologi yang merupakan produk revolusi industri 4.0 dalam proses pendidikan. Artinya, pendidikan tidak dapat dilepaskan dari pengaruh era ini karena salah satu fungsi pendidikan adalah menghasilkan lulusan yang memiliki kompetensi yang dibutuhkan oleh tuntutan era tersebut. Terlepas dari beberapa kritikan para ahli terkait ketidaksetujuannya dalam memahami pendidikan seperti layaknya sebuah pabrik, namun kondisi ini memang tidak dapat dielakkan lagi. Pooworawan menyebutkan bahwa institusi pendidikan diibaratkan sebagai era produksi massal yang menempatkan mahasiswa sebagai produknya, kurikulum sebagai spesifikasi produk, proses ujian sebagai proses quality control, ijazah sebagai kartu garansi, dan institusi pendidikan sebagai brand atau merk produk (Puncreobutr, 2016).

Bila kita cermati, semakin banyak bermunculan platform yang bergerak di bidang pendidikan yang menggunakan aplikasi teknologi informasi saat ini. Berbagai jenis platform pendidikan seperti bimbingan belajar, kursus dan lain-lain kian menyemarakkan dunia pendidikan di era revolusi industri 4.0 ini. Salah satunya yang kini menarik ribuan pengguna adalah Ruangguru. Startup ini makin dilirik oleh generasi milenial di Indonesia terlebih lagi setelah Iqbaal Ramadhan ditunjuk sebagai Brand Ambassador-nya. Startup ini merupakan layanan bimbingan belajar secara online yang dapat diakses dengan 
menggunakan gadget atau smartphone. Artinya, bimbingan belajar tidak lagi dimaknai sebagai proses bimbingan yang berupa sistem face to face antara tutor dan peserta didiknya.

Dengan era yang berbeda, tentu saja kompetensi dan keterampilan yang dibutuhkan oleh dunia kerja akan berbeda pula. Menurut World Economic Forum (2015), ada 16 keterampilan yang harus dikuasai oleh peserta didik yang dikelompokkan menjadi 3 bagian, yaitu foundational literacies, competencies, dan character qualities. Artikel ini mengulas beberapa kompetensi inti yang sangat diharapkan dikuasai oleh mahasiswa dalam menyongsong era revolusi industri 4.0. Berbagai kompetensi tersebut adalah keterampilan berpikir kritis atau problemsolving, kreativitas, berkomunikasi, dan kolaborasi. Lebih lanjut, artikel ini juga menyoroti berbagai pendekatan pembelajaran bahasa di perguruan tinggi dalam mengembangkan keempat keterampilan tersebut.

\section{THE FOUR CS ATAU SUPER SKILLS}

Dengan berubahnya zaman, sudah tidak disangkal lagi jika lapangan pekerjaaan maupun dunia industri juga mengalami perubahan yang berubah secara drastis. Dengan demikian, keterampilan yang harus dikuasai oleh lulusan perguruan tinggi juga berubah atau bahkan makin meluas. Kondisi ini tentu harus segera disikapi secara serius oleh semua kampus di Indonesia. Dengan kata lain, kampus harus mengakomodasi variasi tuntutan perubahan zaman tersebut dengan meredesain dan mereformasi kurikulumnya sehingga mampu menghasilkan lulusan yang tidak hanya terpaku pada kerangka terbatas dalam tataran pemenuhan dalam buku teks saja.

Bagaimana kondisi perguruan tinggi saat ini? Drucker berpendapat bahwa dalam lingkungan akademik (kampus) saat ini, para siswa tidak dapat menunjukkan performansinya dengan baik (Papaleontiou-Louca, Varnava-
Marouchou, Mihai, \& Konis, 2014). Apa yang mereka lakukan hanyalah mengulangi apa yang telah dilakukan oleh orang lain. Dengan kata lain, orisinalitas dan kebaruan telah berakhir.

Menurut beberapa penelitian, kondisi kampus sudah mulai terlihat perubahan namun harus diakui juga bahwa masih banyak lembaga pendidikan tinggi yang mengesampingkan the Four Cs dalam proses pendidikannya. Pada tahun 1965, The Torrance Original Text melakukan penelitian terhadap 1000 pengajar di Jerman, India, Filipina, Yunani, dan Amerika Serikat. Pada penelitian tersebut, hampir semua pengajar di lima negara tersebut memberikan penghargaan/reward terhadap siswa yang berperilaku baik, tugas yang dikumpulkan tepat waktu dan memberikan hukuman bagi siswa yang banyak bertanya atau yang berani memberikan opini. Kondisi pada puluhan tahun lalu ini justru masih terjadi hingga saat ini.

Dari berbagai literatur, banyak penulis yang menyatakan bahwa sistem pendidikan di berbagai negara tidak mempromosikan proses belajar mengajar yang kreatif. Studi di lapangan menyatakan bahwa pengajar menghadapi tantangan dalam mengajarkan The Four Cs karena waktu yang terbatas. Di samping itu juga, tantangan lain muncul dari para siswa sendiri yang memiliki pengetahuan, gairah, motivasi, dan gaya belajar yang berbedabeda (Rusdin, 2018).

Berdasarkan pemaparan World Economic Forum (2015) ada beberapa keterampilan general yang harus dimiliki di era disruptif ini. Keterampilan tersebut adalah: (1) terbuka pada perubahan \& beradaptasi untuk berubah, (2) fleksibilitas kognitif, (3) berpikir inovatif dan adaptif, (4) kemampuan memecahkan masalah, (5) kemampuan mengatur orang, (6) vitual collaboration, (7) kecerdasan emosional, (8) memiliki teknik negosiasi, (9) berorientasi pada pelayanana, dan (10) technical entrepreneurship. Namun jika dikonfrontasikan dari berbagai literatur, 
keterampilan era revolusi industri 4.0 mencakup (1) critical thinking skill, (2) kreatif, (3) komunikatif, dan (4) kolaboratif. Menurut berbagai literatur, keempat keterampilan tersebut disebut dengan istilah super skills atau the four Cs (the 4Cs).

\section{Critical Thinking Skill/Problem Solving}

Seperti yang dijelaskan di atas, salah satu skill yang dibutuhkan di era revolusi industri 4.0 adalah kemampuan berpikir kritis. Critical thinking kadang kala disamakan artinya dengan istilah kreatif. Namun pada dasarnya, keduanya memiliki konstruksi yang berbeda yang dapat dilihat pada perilaku manusia. Secara umum, critical thinking adalah salah satu jenis kemampuan untuk melihat sesuatu kejadian, kondisi, atau pemikiran dengan sudut pandang yang berhati-hati dan membuat komentar, keputusan, serta mempelajari reabilitas dan validitas pengetahuan berdasarkan standar logika dan pemikiran (Birgili, 2015).

Critical thinking tidak dapat dimaknai sebagai sebuah aktivitas berpikir biasa. Berpikir kritis dapat diartikan sebagai sebuah pemikiran yang tidak begitu saja mempercayai apa yang diterimanya namun berupaya untuk melakukan berbagai cara dalam membuktikan kebenaran apa yang diperolehnya. Artinya, keterampilan ini membutuhkan beberapa tahapan atau proses di dalamnya. Jika dikaitkan dengan situasi pada era disrupsi saat ini, kemampuan ini sangat penting dimiliki oleh setiap individu agar dapat membedakan mana yang fakta dan mana yang hoaks.

Menurut Sanavi \& Tarighat (2014) pendefinisian critical thinking dibedakan menjadi tiga bagian, yaitu berdasarkan pada pendekatan filosofis, psikologis, dan pendekatan dalam bidang pendidikan. Definisi yang didasarkan pada pendekatan filosofis difokuskan pada hipotesis para pemikir kritis, daftar berbagai kualitas dan karakteristik pemikir kritis, dan bukan pada tingkah laku atau aksi para pemikir kritis.
Pendekatan psikologis difokuskan pada bagaimana orang-orang berpikir daripada bagaimana mereka berpikir di bawah keadaan. Sedangkan pendekatan berbasis pendidikan, critical thinking dimaknai sebagai kapasitas untuk melampaui informasi yang diberikan, mengadopsi pendirian kritis, mengevaluasi, memiliki kepedulian metakognitif, dan kapasitas dalam mengatasi masalah.

Ada beberapa karakteristik berpikir kritis menurut Nickerson, yaitu: (1) menggunakan bukti-bukti secara objektif dan terampil, (2) mampu mengorganisasikan pikiran, mengekspresikan secara singkat, abstrak dan konsisten, (3) membedakan asumsi yang masuk akal dan mana yang tidak, (4) menunda membuat keputusan karena kurangnya bukti, (5) memahami perbedaan antara rasional dan alasan, (6) mencoba memprediksi kemungkinan hasil atau alternatif tindakan, (7) melihat kesamaan yang samar, (8) belajar secara independen, (9) mengaplikasikan teknik mengatasi masalah, (10) menggunakan argumen yang jelas (Turabik \& Gün, 2016).

Karakteristik lain tentang keterampilan berpikir kritis juga dikemukakan oleh Bayer. Menurutnya, critical thinking skill dapat dikategorikan sebagai: (1) kemampuan membedakan antara kebenaran yang dapat dibuktikan dan pernyataan penting, (2) membuat perbedaan antara informasi yang baik, tuntutan dan justifikasi, (3) menentukan sumber-sumber yang reliabel, (4) mendefinisikan opini yang tidak dapat dibuktikan, (5) mengungkapkan prasangka, (6) kepedulian terhadap kesalahan logika atau kontradiksi, dan (7) menentukan keefektifan sebuah opini (Arslan \& Demirtas, 2016).

\section{Kreativitas}

Secara sederhana kreativitas dikaitkan dengan hal-hal yang menyangkut dengan seni dan talenta artistik. Namun pada perkembangannya, kreativitas juga menyangkut fungsi kognitif yang merujuk 
pada kemampuan dalam membangkitkan konsep dan ide baru dan kemampuan untuk berpikir secara produktif dan berbeda pada domain akademik. Kreativitas didefinisikan sebagai sebuah konstruksi multidimensional termasuk juga di dalamnya adalah variabel kognitif, karakteristik personal, keluarga, aspek pendidikan, dan elemen sosial dan budaya (Nakano \& Wechsler, 2018)

Kreativitas juga berkaitan erat dengan proses mental yang berhubungan dengan proses kognitif manusia (Beyer, 1987). Selain itu, berpikir kreatif juga tergolong dalam kemampuan tingkat tinggi dalam menciptakan sesuatu yang baru yang merupakan keterampilan yang harus dikembangkan di abad ke-21 (Greenstein, 2012). Bahkan dewasa ini, kreativitas diartikan sebagai sebuah integrasi dari berbagai keterampilan seperti keterampilan berpikir ilmiah, entrepreneurship, design thinking, dan matematika (Bialik \& Fadel, 2015).

Dalam perspektif humanistik, orang yang kreatif memiliki kesadaran dan kemampuan untuk mengatasi krisis dengan cara-cara yang transformatif. Artinya, orang kreatif merupakan orang-orang yang berada dalam proses untuk mencapai aktualisasi diri dan mengembangkan karakteristik yang berhubungan dengan kesehatan mentalnya. Oleh karena itu, kreativitas memiliki karakteristik: (1) imajinasi, (2) keterbukaan terhadap pengalaman, (3) keingintahuan, (4) intuisi, (5) pencarian ide, (6) toleransi terhadap ambiguitas, (7) kemandirian, (8) inovasi, (9) wawasan, (10) keterbukaan internal \& eksternal, (11) iluminasi atau wawasan, (12) penemuan masalah, dan (13) citra (Ülger, 2016).

Kreativitas

merupakan

keterampilan yang didukung oleh beberapa komponen yang saling berkaitan. Menurut Amabile dikutip (Fitriah, 2017) ada tiga komponen pendukung kreativitas, yaitu pengetahuan, berpikir kreatif, dan motivasi. Knowledge atau pengetahuan berhubungan dengan segala informasi yang relevan untuk digunakan dalam menciptakan produk atau ide-ide baru. Berpikir kreatif adalah komponen kedua dalam kreativitas yang merupakan pendekatan atau cara yang digunakan oleh tiap-tiap individu untuk menghadapi tantangan dan mengatasi masalah. Terakhir, motivasi merujuk padahasrat atau kesenagan seseorang dalam menagatsi masalah yang bermuara pada penciptaan produk/ide yang kreatif.

\section{Keterampilan Komunikasi}

Keterampilan

komunikasi merupakan jenis keterampilan umum atau generic skills yang harus dikuasai oleh lulusan perguruan tinggi. Komunikasi didefinisikan sebagai sebuah proses pertukaran informasi dari seseorang kepada orang lain/kelompok lain dengan menggunakan simbol-simbol baik melalaui metode verbal maupun non-verbal. Di samping itu, komunikasi juga terkait dengan pertukaran ide, pendapat, maupun informasi dengan objek yang spesifik (Iksan dkk., 2012).

Senada dengan pendapat di atas, komunikasi juga diartikan sebagai proses transmisi makna/arti dari seseorang kepada orang lain baik secara verbal maupun nonverbal. Komunikasi yang dimaksud tersebut tidak terlepas dari beberapa komponen di dalamnya, yaitu konteks, pengirim, penerima, dan pesan itu sendiri (Matin, Jandaghi, Karimi, \& Hamidizadeh, 2010). Untuk itulah, keterampilan berkomunikasi sangat dibutuhkan karena pada hakikatnya komunikasi tidak hanya sekadar berbicara. Ada banyak aspek yang perlu dikuasai oleh siswa agar dapat berkomunikasi dengan baik dan efisien.

Dalam konteks pembelajaran di kelas, pendidik harus mampu memberikan strategi dan metode dalam meningkatkan keefektifan keterampilan berkomunikasi siswa. Dalam mengembangkan kemampuan tersebut, ada berbagai hal yang harus mendapat perhatian pendidik yang dikaitkan dengan era digital saat ini. Beberapa poin tersebut adalah: (1) berkomunikasi dengan media digital untuk 
mendukung pembelajaran individu maupun kelompok, (2) berbagi informasi secara efektif dan efisien dengan menggunakan media digital yang sesuai, dan (3) mengomunikasikan pemikiran dan ide secara jelas dan efektif pada audiens berbeda dengan menggunakan berbagai format dan media.

\section{Kolaborasi}

Kolaborasi menjadi isu yang seksi diperbincangkan memasuki abad ke-21 ini. Hal ini disebakan oleh tuntutan global yang memang mengutamakan kolaborasi dalam menyelesaikan permasalahan dan tujuan bersama. Sebagaimana kita ketahui bahwa kebutuhan masyarakat untuk berpikir dan bekerja sama pada isu-isu kritis meningkat secara drastis. Hal ini mendasari oleh terjadinya pergeseran dari usaha-usaha individu ke arah kelompok atau komunitas (Handajani, Pratiwi, \& Mardiyana, 2018).

Istilah kolaborasi tidak sekadar dimaknai sebagai kerja secara bersamasama dalam satu kelompok saja. Pada hakikatnya, kolaborasi merupakan upaya bersama dalam satu komunitas dalam bersosialisasi dan mengontrol ego atau emosi pribadi. Kolaborasi diartikan juga sebagai kelompok kecil yang terdiri dari dua orang atau lebih yang: (1) berinteraksi sesamanya, (2) saling bergantung, (3) mendefiniskan mereka sebagai milik kelompok, (4) saling berbagi norma dan aturan, (5) saling mempengaruhi, (6) saling menghargai, dan (7) meraih tujuan yang sama (Johnson \& Johnson, dalam Stryron, 2014).

National Education Association
(2015) menyatakan bahwa kolaborasi sebagai unsur utama keberhasilan siswa di dunia global dan masyarakat teknologi saat ini. Dengan demikian, guru perlu menunjukkan bagaimana rasanya bekerja dengan saling menghormati dalam kelompok yang beragam. Artinya, kolaborasi dapat dicapai dengan merangkul keberagaman dan saling toleransi antaranggota kelompok. Kolaborasi merupakan aktivitas yang terjadi jika dua orang atau lebih saling bekerja sama untuk mencapai tujuan yang telah ditetapkan bersama-sama. Agar dapat berkolaborasi dengan baik, maka peserta didik harus belajar untuk: (1) bekerja secara efektif dengan anggota grup/kelompok yang berbeda, termasuk orang-orang dari latar budaya yang berbeda, (2) bersikap fleksibel dan berupaya untuk kompromi dengan anggota lain dalam mencapai tujuan, dan (3) menunjukkan tanggung jawab bersama dalam mencapai tujuan.

\section{IMPLEMENTASI THE 4CS DALAM PEMBELAJARAN BAHASA}

Pengintegrasian The Four Cs dalam pembelajaran Mata Kuliah Bahasa Indonesia dapat dilakukan oleh dosen melalui dua keterampilan berbahasa yang bersifat produktif, yaitu keterampilan menulis dan keterampilan berbicara. Namun demikian, The Four Cs juga dapat diimplementasikan dalam pembelajaran menyimak dan membaca. Dalam artikel ini, pembahasan hanya difokuskan pada pembelajaran menulis dan berbicara saja. Mengingat saat ini mayoritas siswa merupakan generasi $\mathrm{Z}$ maka sebaiknya sistem pembelajaran lebih banyak memanfaatkan teknologi. Pembelajaran dengan sistem ini diyakini dapat memacu semangat dan motivasi belajar bagi para peserta didik saat ini.

\section{Pembelajaran Menulis}

Pengembangan

keterampilan berpikir kritis dapat dikembangkan dalam berbagai materi pelajaran, salah satunya dengan pembelajaran menulis akademik pada mata kuliah Bahasa Indonesia di perguruan tinggi. Hal ini senada dengan hasil penelitian yang dikemukakan oleh Alidmat \& Ayassrah (2017) yang menyatakan bahwa pengembangan keterampilan berpikir kritis dapat ditingkatkan melalui tugas-tugas menulis. Jika dikaitkan dengan pembelajaran era revolusi industri 4.0, keterampilan berpikir kritis dapat pula dikembangkan melalui proses pembelajaran berbasis teknologi. 
Salah satunya dengan program blended learning. Keterampilan berpikir kritis siswa juga dapat dikembangkan melalui pembelajaran menulis dengan berbasis internet (internet-based environment). Ada beberapa alasan yang ditemukan dalam pembelajaran ini, yaitu: (1) para siswa menggunakan keterampilan berpikir kritisnya saat mencari informasi tentang topik dari mesin pencari informasi, (2) kolaboratif alami pada text-based chat dapat meningkatkan kemampuan berpikir kritis siswa, (3) penekanan pada kegiatan menulis sebagai proses aktivitas dan berpikir, dan (4) tugas menulis yang diberikan kepada siswa merupakan kran dalam mengembangkan keterampilan berpikir kritis.

Merujuk pada beberapa studi tersebut, dosen dapat mendesain pembelajaran menulis paragraf bebas dengan menggunakan media sosial Instagram. Para mahasiswa dikelompokkan menjadi beberapa grup dengan mempertimbangkan keberagaman anggotanya, baik perbedaan dari jenis kelamin, suku, maupun perbedaan kemampuan kognitif. Setiap kelompok diwajibkan mem-posting sebuah foto bertema bebas yang kemudian diberi caption yang sesuai atau cocok. Kegiatan ini dapat mengembangkan semua keterampilan The Four Cs, yaitu keterampilan berpikir kritis, kreativitas, komunikasi, dan kolaborasi.

Keterampilan berpikir kritis dapat terlihat pada proses memilih foto dan menulis caption sebelum diunggah di Instagram. Kejelian dan kemampuan kritis mahasiswa diasah melalui penentuan foto dengan segala pertimbangannya yang berkaitan dengan isu-isu sosial yang sedang ramai diperbincangkan publik. Pada proses ini, keterampilan kolaborasi juga dapat diasah dengan berusaha mencapai satu kesepakatan tanpa memaksakan pendapat individu. Keterampilan komunikasi dilatih melaului proses menulis yang merupakan proses menyimbolkan ide-ide ke dalam rangkaian kata-kata. selanjutnya, keterampilan kreativitas ditujukkan dengan orisinalitas dan keontentikan foto yang mereka pilih. Diharapkan foto yang diunggah merupakan hasil bidikan kamera mahasiswa bukan mengambil dari Instagram maupun sumber lain.

\section{Pembelajaran Berbicara}

Pembelajaran berbicara atau speaking teaching berkaitan erat dengan keterampilan komunikasi. Di samping itu juga, berbicara juga berhubungan dengan keterampilan abad ke-21 lainnya. Penggunaan teknologi juga dapat dimaksimalkan dalam pembelajaran berbicara ini dengan menggunakan berbagai teknilogi maupun beberapa platform media sosial. Maka dari itu, penggunaaan youtube, blog, Instagram, facebook, maupun WhatsApp sering dijumpai dalam proses pembelajaran di kelas.

Strategi pembelajaran materi berbicara yang paling sederhana dapat dilakukan dengan mengakses youtube. Kanal youtube merupakan media yang memiliki fitur seperti akun pribadi lainnya. Kanal pada youtube tersebut digunakan untuk mengunggah video, memberikan tanda like, dislike, memberi komentar, membuat daftar putar (playlist) hingga menjadi pelanggan atau subscriber (Karch dikutip Sari, 2017). Dosen dapat mengunduh video atau mengakses ke youtube dengan memilih konten yang berkaitan dengan public speaking yang kemudian dikomentari dan didiskusikan bersama-sama tentang kelebihan dan kekurangannya.

Namun ada hal-hal yang harus diperhatikan oleh dosen ketika memilih konten pada youtube sebagai media dalam pembelajaran berbicara. Pemilihan konten di yotube harus memperhatikan: (1) kesesuaian konten dengan karakteristik mahasiswa baik yang berkaitan dengan usia, jenis kelamin, etnis, dan dominasi bahasa, (2) menghindari konten yang mengandung kekerasan, bahasa vulgar, dan pornografi, dan (3) struktur video yang 
berkaitan dengan durasi video, konteks, visual, dan lain-lain (Berk, 2009).

Selanjutnya, strategi pembelajaran berbicara dapat juga dilakukan dengan menggunkan platform media sosial Instagram. Strategi ini dimulai dengan meminta para mahasiswa untuk memposting video dengan durasi minimal 1 menit tentang pendapat mereka yang berhubungan dengan suatu topik atau fenomena (Anggraeni, 2018). Selanjutnya, setipa mahasiswa diwajibkan untuk memberikan komentar dengan batas waktu yang lebih fleksibel (seminggu).

Penggunaan media sosial Instagram lebih mudah digunakan karena hampir semua mahasiswa memiliki akun media sosial ini. Ada beberapa pertimbangan yang melatarbelakangi pemilihan Instagram ini sebagai media pembelajaran, yaitu:

1) pertumbuhan Instagram yang meningkat drastis hingga digunakan sekitar 300 sampai dengan 500 juta pengguna aktif per bulan

2) durasi video yang pendek menjadi faktor penting dalam mendorong pembelajaran bahasa sehingga mahasiswa terlatih untuk fokus dan lebih perhatian

3) tidak adanya opsi jeda dalam durasi video instagram membuat pendengar harus fokus terhadap suara/konten video.

4) Instagram memiliki interface yang cerah dan interaktif sehingga menarik bagi mahasiswa generasi $\mathrm{Z}$ (Khalitova \& Gimaletdinova, 2016). Aplikasi berbagai keterampilan The Four $C s$ tersebut dapat dilihat dari beberapa aktivitas pembelajarannya. Dengan aktivitas merekam video sebelum diposting, mahasiswa akan terlatih berpikir kritis untuk mencari ide-ide maupun topik pembahasan. Mahasiswa diperkenankan oleh dosen untuk mengakses internet dalam menemukan ide yang hendak diangkatnya. Dengan memilih salah satu topik pembicaraan, para mahasiswa tentu telah mempertimbangkan berbagai alasan yang mendasari keputusannya tersebut.
Fenomena yang sedang terjadi, kejadian di sekitar kita, hingga diskursus yang menyangkut isu global dapat dijadikan sebagai alasan dalam memilih topik pembicaraan.

Kreativitas dalam membuat video juga perlu diperhatikan oleh para mahasiswa. Orang yang memiliki kreativitas tinggi pasti merasa tertantang untuk membuat video yang menarik dan berbeda dari yang sudah ada. Kreativitas dalam pembuatan video dapat berkaitan dengan durasi video, pemilihan lokasi, pencahayaan, background pada video dan lain-lain. Mahasiswa juga dapat menggunakan kemampuan dalam olah pengeditan agar video menjadi lebih menarik. Beberapa bagian yang dapat diedit tersebut antara lain memasukkan ilustrasi musik, menambahkan efek gambar atau suara, dan lain-lain. Jika memungkinkan, dosen dapat merekomendasikan berbagai aplikasi yang dapat digunakan dalam pengeditan video tersebut.

\section{KESIMPULAN}

Dalam menongsong abad ke-21 dan hadirnya era revolusi industri 4.0, peran perguruan tinggi harus difokuskan pada proses pembelajaran yang mengajarkan berbagai keterampilan penting yang biasa disebut dengan istilah The Four Cs. Beberapa keterampilan abad ke-21 tersebut adalah keteranpilan berpikir kritis dan problem solving, kreativitas, kolaborasi, dan komunikasi. Keempat keterampilan tersebut menjadi skills yang mutlak diperlukan oleh lulusan perguruan tinggi dalam memasuki dunia kerja era revolusi industri 4.0.

Dewasa ini, mahasiswa di perguruan tinggi merupakan generasi $\mathrm{Z}$ yang memiliki karakteristik unik dan berbeda dari generasi sebelumnya. Untuk itulah, desain aktivitas pembelajaran di perguruan tinggi harus disesuaikan dengan karakteristik generasi tersebut. Salah satunya dengan memanfaatkan teknologi digital ke dalam proses pembelajaran. Dalam kelas bahasa Indonesia, 
pengintegrasian The Four Cs dilakukan dalam pembelajaran keterampilan menulis dan berbicara dengan bantuan teknologi yaitu dengan memanfaatkan beberapa platform media sosial, seperti WhatsApp, Instagram, dan Youtube.

Pembelajaran menulis dan berbicara dengan memanfaatkan media sosial akan melatih berbagai keterampilan abad ke-21. Pertama, pada proses pencarian ide/topik tulisan/pembicaraan, kemampuan berpikir kritis dan problem solving dilatih dengan mencari berbagai referensi yang akhirnya dijadikan topik dengan berbagai argumentasinya. Kedua, sebelum menentukan topik yang hendak diangkat, beberapa mahasiswa dalam satu kelompok berdiskusi untuk menentukan kesepakatan tentang topik yang hendak dipilih. Dalam konteks ini, keterampilan kolaborasi didemonstrasikan agar kelompok tersebut mencapai kesepakatan bersama. Ketiga, kreativitas mahasiswa dapat diasah dengan membuat video public speaking dengan memperhatikan durasi, efek video atau musik, dan lain-lain. Terakhir, keterampilan komunikasi bagi mahasiswa dilatih dengan aktivitas dalam menyampaikan pendapat, pemilihan katakata/diksi, penggunaan intonasi suara yang tepat, artikulasi yang jelas dan lain-lain.

\section{DAFTAR PUSTAKA}

Alidmat, A. O. H., \& Ayassrah, M. A. (2017). Development of Critical Thinking Skills through Writing Tasks: Challenges Facing Maritime English Students at Aqaba College, AlBalqa Applied University, Jordan. International Journal of Higher Education, 6(3), 82-90.

Anggraeni, C. W. (2018). Promoting Education 4.0 in English for Survival Class: What are the Challenges? Metathesis: Journal of English Language, Literature, and Teaching, 2(1), 12.

Arslan, S., \& Demirtas, Z. (2016). Social Emotional Learning and Critical
Thinking Disposition. Studia Psychologica, 58(4), 276-285.

Berk, R.A. (2009). Multimedia Teaching with Video Clips: TV, Movies, Youtube, and mtvU in the College Classroom. International Journal of Technology in Teaching and Learning, 5(1), 1-21.

Beyer, B. (1987). Practical Strategies for Teaching of Thinking. Boston: Allynannd Bacon Inc.

Bialik, M., \& Fadel, C. (2015). Skills for the 21: What should Students Learn? Boston.

Birgili, B. (2015). Creative and Critical Thinking Skills in Problem-based Learning Environments. Journal of Gifted Education and Creativity, 2(2), 71-71.

Fitriah, F. (2017). Teachers' Beliefs about Creativity in EFL Classrooms in Indonesian Higher Education. Canbera.

Freeman, I. M. (2016). Life Skills for 21st Century Learners. International Journal of Education and Social Science, 3(10), 49-52.

Greenstein, L. (2012). Assesing Skill 21st Century. A Guide to Evaluating Mastery and Authentic Learning. New York: Crowin A SAGE Company.

Handajani, S., Pratiwi, H., \& Mardiyana, M. (2018). The 21st Century Skills with Model Eliciting Activities on Linear Program. In IOP Conferences series: Journal of Physics: Conference Series (Vol. 108, pp. 1-7).

Iksan, Z. H., Zakaria, E., Meerah, T. S. M., Osman, K., Lian, D. K. C., Mahmud, S. N. D., \& Krish, P. (2012). Communication Skills Among University Students. Procedia -Social and Behavioral Sciences, 59, 71-76.

Janíková, M., \& Kowaliková, P. (2017). Technical Education in the Context of the Fourth Industrial Revolution. Journal for Research and 
Education, Spesial Issue (December), 65-73.

Khalitova, L., \& Gimaletdinova, G. (2016). Mobile Technologies in Teaching English as A Foreign Language in Higher Education: A Case Study of Using Mobile Application Instagram. Dalam ICERI 2016, The 9th International Conference of Education, Research, and Innovation. Seville Spanyol: Kazan Federal University.

Levin-Goldberg, J. (2012). Teaching Generation TechX with the 4Cs: Using Technology to Integrate $21 \mathrm{st}$ Century Skills. Journal of Instructional Research, 1(1), 5966.

Matin, H. Z., Jandaghi, G., Karimi, F. H., \& Hamidizadeh, A. (2010). Relationship between Interpersonal Communication Skills and Organizational Commitment (Case Study: Jahad Keshavarzi and University of Qom, Iran). European Journal of Social Sciences, 13(3), 387-398.

Nakano, T. D. C., \& Wechsler, S. M. (2018). Creativity and Innovation: Skills for the 21st Century. Estudos de Psicologia (Campinas), 35(3), 237-246.

National Education Association. (2015). Preparing $21^{\text {st }}$ Century Students for a Global Society. http://www.nea.org/ assets/docs/AGuided-to-Four-Cs.pdf

Papaleontiou-Louca, E., VarnavaMarouchou, D., Mihai, S., \& Konis, E. (2014). Teaching for Creativity in Universities. Journal of Education and Human Development, 3(4), 131-154.

Puncreobutr, V. (2016). Education 4.0: New Challenge of Learning. St.Therasa Journal of Humanities and Social Sociences, 2(2), 92-97.

Rusdin, N. M. (2018). Teachers' Readiness in Implementing 21st Century Learning. International Journal of
Academic Research in Business and Social Sciences, 8(4), 1293-1306.

Sanavi, R. V., \& Tarighat, S. (2014). Critical Thinking and Speaking Proficiency: A Mixed-method Study. Theory and Practice in Language Studies, 4(1), 79-87.

Sari, P. (2017). Using Vlog in the Youtube Channel as a Means To Improve Students' Motivation And Confidence to Speak English in Intermediate 1 Level of LB-LIA Jambi. International Journal of English Language Teaching, 1(1), 38-44.

Stryron, R. A. (2014). Critical Thinking and Collaboration: A Strategy to Enhance Student Learning. Systemics, Cybernetics and Informatics, 12(7), 561-565.

Sumardianta, J., \& AW, W. K. (2018). Mendidik Generasi $Z$ \& A. Jakarta: Grasindo.

Turabik, T., \& Gün, F. (2016). The Relationship between Teachers' Democratic Classroom Management Attitudes and Students' Critical Thinking Dispositions. Journal of Education and Training Studies, 4(12), 45-57.

Ülger, K. (2016). The Relationship between Creative Thinking and Critical Thinking Skills of Students. Hacettepe University Journal of Education, 31(4).

World Economic Forum. (2015). New Vision for Education: Unlocking the Potential of Technology. Geneva: WEF 